DOI:

Ірина Пінчук, кандидат педагогічних наук, докторант Глухівського начіонального педагогічного університету імені Олександра Довженка

\title{
ОРГАНІЗАЦІЯ ПЕДАГОГІЧНОГО ЕКСПЕРИМЕНТУ 3 ФОРМУВАННЯ ІНШОМОВНОЇ КОМУНІКАТИВНОЇ КОМПЕТЕНТНОСТІ МАЙБУТНІХ УЧИТЕЛІВ ПОЧАТКОВОЇ ШКОЛИ
}

У статті описано особливості організачії та проведення експериментального дослідження 3 формування іншомовної комунікативної компетентності майбутніх учителів початкової школи. Дослідження передбачало проведення педагогічного експерименту з метою імплементацї таких етапів: пошуковотеоретичного, діагностико-констатувального, поглиблювально-формувального та аналітикоузагальнювального.

Ключові слова: педагогічний експеримент; етапи експерименту; іниомовна комунікативна компетентність; майбутні вчителі початкової иколи; дослідне навчання.

Рис. 2. Табл. 2. Літ. 12.

Iryna Pinchuk, Ph.D.(Pedagogy), Doctoral Student of Hlukhiv Oleksandr Dovzhenko National Pedagogical University

\section{ORGANIZATIONOF PEDAGOGICALEXPERIMENTFORFORMINGFOREIGNLANGUAGE COMMUNICATIVE COMPETENCE OFINTENDINGPRIMARY SCHOOLTEACHERS}

The article deals with the peculiarities of organizing and conducting the experimental research on forming the foreign language communicative competence of intending primary school teachers. The study aimed at conducting the pedagogical experiment, which involved the implementation of the following stages: search-theoretical, diagnostic-ascertaining, deepening-forming and analytical-generalizing. The characteristic features of the pedagogical experiment are: deliberate implementation of fundamentally important changes in accordance with the tasks and hypotheses of the study; organization of the educational process, which allows to establish links between phenomena without violating its holistic nature; in-depth qualitative analysis and accurate quantitative measurement of new or modified components introduced into the educational process and the results of the experiment in general. In the process of organizing the experimental work, the complexity, versatility and multicomponent nature of the process of forming foreign language communicative competence of intending primary school teachers were taken into account. According to the logic of pedagogical search, the scheme of pedagogical experiment research was developed.

Keywords: pedagogical experiment; experiment stages; foreign language communicative competence; intending primary school teachers; research training.

П остановка проблеми. Реформування освітньої галузі залежить від підготовленості компетентних учителів початкової школи, фахівців нової генерації, здатних продуктивно й цілеспрямовано діяти в сучасних умовах початкової школи, ефективно й водночас із відповідальністю виконувати свій обов'язок. Сучасні вимоги до підготовки кваліфікованих фахівців передбачають передовсім їхю участь в усіх глобалізаційних процесах, бути конкурентноспроможними.

Конкурентоспроможність базується на конкурентоздатності, яка доповнюється оволодінням здобувачами освіти актуальними знаннями і вміннями згідно з потребами ринку праці. Тобто призначенням закладів вищої (професійної)освітиєпідпотовка конкурентоспроможних випускників. Досягається це шляхом вдосконалення параметрів конкурентоздатності, що формується ще в школі, і виконанням професійних стандартів [5]. Відтак вони повинні бути активними учасниками процесу міжнародної комунікації та мати необхідний комунікативний іншомовний досвід у сферах професійного та ситуаційного спілкування в усній і письмовій формах. 3 огляду на це актуальним є питання формування іншомовної комунікативної компетентності (ІКК) майбутніх учителів початкової школи в закладах вищої освіти, що сприятиме підвищенню їхньої мобільності та конкурентоспроможності.

Аналіз останніх досліджень і публікацій. Дослідження процесу формування ІКК майбутніх учителів початкової школи в процесі професійної підготовки на факультетах початкової освіти передбачав організацію та проведення педагогічного експерименту. 3 метою пояснення 


\section{ОРГАНІЗАЦІЯ ПЕДАГОГІЧНОГО ЕКСПЕРИМЕНТУ 3 ФОРМУВАННЯ ІНШОМОВНОӤ КОМУНІКАТИВНОӤ КОМПЕТЕНТНОСТІ МАЙБУТНІХУЧИТЕЛІВ ПОЧАТКОВОЇ ШКОЛИ}

специфіки й логіки його здійснення вважаємо за доцільне проаналізувати категорії “експеримент”, “педагогічний експеримент".

Дефініція “експеримент" має досить багато різних тлумачень та походить з латинської мови і в перекладі означає “дослід, спроба".

У короткій філософській енциклопедії $[8,535]$ експеримент визначається як “планомірно проведене спостереження; планомірна ізоляція, комбінація і варіювання умов 3 метою вивчення залежних від них явищ”. 3 огляду на це вчений створює можливість спостережень, на основі яких складається нове знання про закономірності досліджуваного явища; а спостереження, умови, знання про закономірності $є$ найбільш істотними ознаками цього визначення.

У психологічному словнику [7] поняття експерименту розглядається як один із основних (разом зі спостереженням) методів наукового пізнання взагалі, психологічного дослідження зокрема. Експеримент відрізняється від спостереження активним втручанням дослідника, що здійснює планомірне маніпулювання однією або декількома змінними і реєстрацію супровідних змін у поведінці досліджуваного објєкта у ситуацію.

Педагогічний експеримент - це метод збору педагогічних фактів в спеціально створених умовах, що дають можливість вивчення та перевірки педагогічних впливів відповідно до проблеми дослідження; метод пізнання, в процесі якого психолого-педагогічні явища вивчаються у спеціально створених або контрольованих умовах $[10,436]$. Окрім того, зазначений метод - це спеціально організований досвід діагностики й перетворення педагогічної діяльності у строго фіксованих і навмисно варійованих умовах, що дає змогу виявити ступінь впливу окремих факторів чи умов на результати процесу. Правильно організований експеримент уможливлює перевіряти гіпотези про причинно-наслідкові відносини, не обмежуючись констатацією звјязку (кореляції) між змінними. Найбільш істотними ознаками є: активність дослідника, характерна для пошукового й формувального типів експерименту, а також перевірка гіпотези.

Однак деякі вчені наголошують, що експеримент $\epsilon$ не методом, а рідше групою методів [6, 5]. Зокрема, вважаємо важливою думку В. Загв'язинського про те, що експериментом називається зміна або відтворення явища 3 метою вивчення його в найбільш сприятливих умовах [6, 127]. Характерною рисою експерименту виступає заплановане втручання у досліджуване явище, можливість його багаторазового відтворення у варійованих умовах. Дидактичний експеримент, на думку В. Загв'язинського [6, 128], дає змогу розкласти цілісне педагогічне явище на складники, в ході варіювання умов функціонування яких дослідник може стежити за розвитком або зміною окремих факторів, фіксуючи окремі результати. Відтак експеримент є засобом перевірки гіпотези, уточнення окремих висновків теорії (емпірично перевірених наслідків), установлення й уточнення фактів.

Щодо методики викладання іноземних мов, М. Ляховицький розглядає експеримент як метод пізнання закономірних зв'язків процесу навчання іноземної мови за допомогою досвіду, в якому зв'язки окремих елементів освітнього процесу варіюються в умовах, що враховуються, а об' єктом є процес навчання іноземної мови в його загальних та окремих проявах [9,3].

Аналіз наукових джерел дає підставу стверджувати, що в загальному розумінні поняття “експеримент” розуміється по-різному, зокрема як: науково-обгрунтований досвід; перевірка гіпотези; відтворення кимось розробленої методики (технології) в нових умовах іншим педагогом; метод пізнання, за допомогою якого в природних або штучно створених контрольованих і керованих умовах досліджується явище, триває пошук нових способів розв'язання проблем; чітко спрямована й контрольована освітня діяльність 3 метою створення й апробування нових освітніх технологій.

На засадах виділення істотних ознак вищенаведених визначень, у статті можемо представити інтегральну версію узагальненого поняття: “експеримент” - це дослідницька діяльність, спрямована на перевірку висунутої гіпотези, яка відбувається в природних або штучно створених контрольованих умовах, результатом якої є виділення істотних факторів, які впливають на освітню діяльність.

Характерними особливостями педагогічного експерименту є: навмисне внесення принципово важливих змін відповідно до завдань та гіпотези дослідження; організація освітнього процесу, що дає змогу встановлювати звјязки між явищами без порушення його цілісного характеру; глибокий якісний аналіз і точний кількісний вимір внесених в освітній процес нових або видозмінених компонентів і результатів експерименту загалом.

Методології експерименту в педагогічних дослідженнях присвячено праці П. Гурвича, В. Краєвського, Ю. Пассова [11]. Вибір методики експерименту $є$ дуже важливою умовою. Педагогічний експеримент має певну структуру 


\section{ОРГАНІЗАЦІЯ ПЕДАГОГІЧНОГО ЕКСПЕРИМЕНТУ 3 ФОРМУВАННЯ ІНШОМОВНОӤ КОМУНІКАТИВНОЇ КОМПЕТЕНТНОСТІ МАЙБУТНІХУЧИТЕЛІВ ПОЧАТКОВОЇ ШКОЛИ}

й логіку проведення, що пов'язано 3 дослідницькими операціями та їх класифікацією. Відповідно різні дослідники виділяють різні етапи цього процесу. Зокрема, Ю. Сурмін вважає, що методика експерименту охоплює п'ять операцій: вибір або розробка методичної схеми експерименту, засоби перетворення објєкта, визначення тривалості експерименту, розроблення засобів і методики вимірювання, контролю й аналізу результатів.

Відповідно до поглядів В. Загвязинського й М. Поташника, сучасна методика викладання іноземних мов як наука виокремлює в експерименті такі фази: 1) організація експерименту (підготовка експерименту); 2) його реалізація проведення; 3) констатація отриманих даних (оцінка результатів експерименту); 4) інтерпретація даних $[6,84]$.

Етапами методичного експерименту 3 перевірки ефективності взаємопов'язаного формування у майбутніх викладачів англійської мови професійно орієнтованої компетентності в говорінні та інформаційно-комунікаційної компетентності в дослідженні М. Бурак [3] є: підготовчий; доекспериментального оцінювання; експериментального навчання; післяекспериментального оцінювання; інтерпретації отриманих даних.

Вітчизняна дослідниця Н. Бершадська [2] пропонує проведення експерименту з формування англомовної усної дискурсивної компетентності студентів мовних спеціальностей, що передбачало реалізацію таких етапів: пошуково-розвідувального, констатувального, формувального і прикінцевого.

На думку I. Вяхк [4], педагогічний експеримент з формування ІКК майбутніх фахівців у галузі інформаційних технологій може складатися з трьох елементів: констатувального; пошукового; формувального.

Педагогічний експеримент 3 формування фахової ІКК майбутніх магістрів іноземної філології, що проводився Д. Бегекою [1], передбачав два основні етапи: констатувальний і формувальний.

Натомість Л. Шиянюк [12] виділяє аксіологічномотиваційний, когнітивно-накопичувальний та поглиблювально- формувальний етапи експериментального навчання.

Процес дослідницько-експериментального навчання Т. Тюльпи передбачав чотири етапи педагогічного експерименту: пошуковотеоретичний, діагностично-констатувальний, формувальний та аналітично-підсумковий.

Мета статті-описати особливості організації та проведення педагогічного експерименту 3 формування іншомовної комунікативної компетентності майбутніх учителів початкової школи в процесі професійної підготовки в педагогічних ЗВО України.

Виклад основного матеріалу. Різноманітність чинних у педагогіці дослідних програм, реальних контекстів дослідження (теоретичних і практичних завдань), можливостей, якими володіє дослідник, а також технічних та етичних обмежень, які виникають у науково-дослідницькій практиці, спричиняють те, що конкретні методики дослідження істотно різняться. Такі конкретні стратегії організації наукових розвідок розглядаються як методи науково-педагогічного дослідження, застосування яких спрямовувалося на отримання методологічних, теоретичних та практичних висновків.

3 огляду на це авторська експериментальна система формування ІКК майбутніх учителів початкової школи пройшла процедуру апробації 3 метою іiї подальшої адаптації та впровадження. Мета дослідницько-експериментальної роботи полягала в дослідженні результативності розробленої системи в процесі професійної підготовки майбутніх фахівців початкової освіти.

Відповідно до цілей та логіки проведення дослідницько-експериментальної роботи, було визначено й обгрунтовано етапи іiі реалізації, що

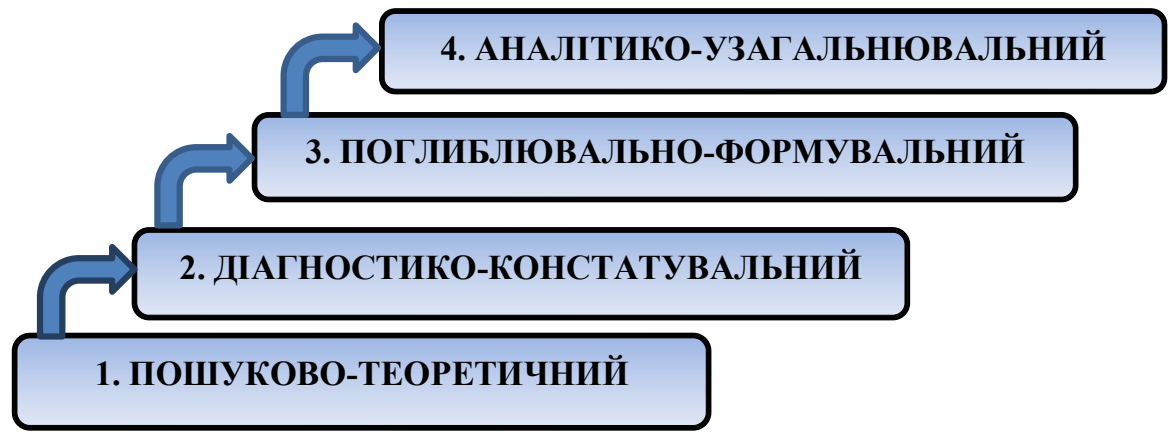

Рис. 1. Етапи педагогічного експерименту з формування ІКК майбутніх учителів початкової школи 


\section{ОРГАНІЗАЦЯ ПЕДАГОГІЧНОГО ЕКСПЕРИМЕНТУ 3 ФОРМУВАННЯ ІНШОМОВНОӤ КОМУНІКАТИВНОЇ КОМПЕТЕНТНОСТІ МАЙБУТНІХ УЧИТЕЛІВ ПОЧАТКОВОӤ ШКОЛИ}

характеризувалися певними завданнями, відповідними формами й методами організації: пошуково-теоретичний, діагностико-констатувальний, поглиблювально-формувальний та аналітикоузагальнювальний (рис.1).

Вибір методів дослідження визначався характером фактичного матеріалу, умовами й метою дослідження. Методи добиралися відповідно до завдань конкретного етапу дослідження. Прийоми й операції з теоретичним і фактичним матеріалом здійснювалися у послідовності, заданій програмою дослідження див. (табл. 1).

У процесі організації експериментальної роботи

Таблиця 1.

Програма дослідження процесу формування іншомовної комунікативної компетентності майбутніх учителів початкової школи

\begin{tabular}{|c|c|c|c|c|}
\hline № & Зміст роботи & Метод & Передбачуваний результат & Термін \\
\hline \multicolumn{5}{|c|}{ І етап експерименту (2015-2017 н. р.) - пошуково-теоретичний } \\
\hline 1 & $\begin{array}{l}\text { Аналіз філософської, } \\
\text { психолого-педагогічної } \\
\text { літератури та практики } \\
\text { сучасного стану } \\
\text { розробленості проблеми } \\
\text { оцінювання формування ІКК } \\
\text { майбутніх учителів } \\
\text { початкової школи }\end{array}$ & $\begin{array}{c}\text { Аналіз } \\
\text { літератури, } \\
\text { логічні операції }\end{array}$ & $\begin{array}{l}\text { Відомості про сучасний стан } \\
\text { досліджуваної проблеми }\end{array}$ & $\begin{array}{l}\text { Жовтень } \\
2015 \text { р. - } \\
\text { травень } \\
2016 \text { р. }\end{array}$ \\
\hline 2 & $\begin{array}{l}\text { Розроблення програми } \\
\text { експерименту }\end{array}$ & $\begin{array}{c}\text { Аналіз, синтез, } \\
\text { індукція }\end{array}$ & $\begin{array}{l}\text { Постановка мети, об’єкту, } \\
\text { предмету, завдань, методів, } \\
\text { визначення залежної і незалежної } \\
\text { змінних програми експерименту }\end{array}$ & $\begin{array}{c}\text { Вересень- } \\
\text { грудень } \\
2016 \text { р. }\end{array}$ \\
\hline 3 & $\begin{array}{l}\text { Аналіз та обгрунтування } \\
\text { робочого визначення поняття } \\
\text { “іншомовна комунікативна } \\
\text { компетентність майбутніх } \\
\text { учителів початкової школи” }\end{array}$ & $\begin{array}{c}\text { Понятійний } \\
\text { аналіз }\end{array}$ & $\begin{array}{l}\text { Визначення сутності поняття } \\
\text { “іншомовна комунікативна } \\
\text { компетентність майбутніх } \\
\text { учителів початкової школи” }\end{array}$ & $\begin{array}{l}\text { Січень - } \\
\text { червень } \\
2017 \text { р. }\end{array}$ \\
\hline 4 & $\begin{array}{l}\text { Аналіз та визначення } \\
\text { структури ІКК майбутніх } \\
\text { учителів початкової школи, } \\
\text { обгрунтування їі компонентів }\end{array}$ & $\begin{array}{c}\text { Аналіз } \\
\text { літератури, } \\
\text { логічні операції }\end{array}$ & $\begin{array}{l}\text { Визначення структури ІКК } \\
\text { майбутніх учителів початкової } \\
\text { школи: перелік компонентів та їх } \\
\text { характеристика }\end{array}$ & \\
\hline 5 & $\begin{array}{l}\text { Аналіз систем оцінювання } \\
\text { рівнів сформованості ІКК } \\
\text { майбутніх учителів } \\
\text { початкової школи в процесі } \\
\text { навчання та визначення } \\
\text { критеріїв, показників }\end{array}$ & $\begin{array}{c}\text { Аналіз } \\
\text { літератури, } \\
\text { логічні операції }\end{array}$ & $\begin{array}{l}\text { Зміст систем оцінювання рівнів } \\
\text { сформованості ІКК майбутніх } \\
\text { учителів початкової школи в } \\
\text { процесі навчання та визначення } \\
\text { критеріїв, показників }\end{array}$ & \\
\hline 6 & $\begin{array}{l}\text { Обгрунтування структури та } \\
\text { рівнів сформованості ІКК } \\
\text { майбутніх учителів }\end{array}$ & Логічні операції & $\begin{array}{l}\text { Структура та зміст рівнів } \\
\text { сформованості ІКК майбутніх } \\
\text { учителів початкової школи }\end{array}$ & \\
\hline
\end{tabular}

II етап експерименту (2017 - 2018 н. p.) - діагностико-констатувальний

\begin{tabular}{|c|c|c|c|c|}
\hline 1 & $\begin{array}{l}\text { Визначення засобів та } \\
\text { прийомів формування IКК } \\
\text { майбутніх учителів } \\
\text { початкової школи }\end{array}$ & $\begin{array}{c}\text { Аналіз } \\
\text { документів, } \\
\text { логічні операції, } \\
\text { спостереження }\end{array}$ & $\begin{array}{l}\text { Засоби та прийоми формування } \\
\text { ІКК }\end{array}$ & $\begin{array}{c}\text { Вересень- } \\
\text { грудень } \\
2017 \text { р. }\end{array}$ \\
\hline 2 & $\begin{array}{l}\text { Розроблення системи } \\
\text { оцінювання рівнів } \\
\text { сформованості ІКК майбутніх } \\
\text { учителів початкової школи та } \\
\text { їх критеріїв }\end{array}$ & Логічні операції & $\begin{array}{l}\text { Система оцінювання рівнів } \\
\text { сформованості ІКК майбутніх } \\
\text { учителів початкової школи та їх } \\
\text { критеріїв }\end{array}$ & \\
\hline
\end{tabular}


ОРГАНІЗАЦІ ПЕДАГОГІЧНОГО ЕКСПЕРИМЕНТУ 3 ФОРМУВАННЯ ІНШОМОВНОӤ КОМУНІКАТИВНОӤ КОМПЕТЕНТНОСТІ МАЙБУТНІХУЧИТЕЛІВ ПОЧАТКОВОЇ ШКОЛИ

\begin{tabular}{|c|c|c|c|c|}
\hline & & & \multicolumn{2}{|c|}{ Продовження таблиц 1.} \\
\hline 3 & $\begin{array}{l}\text { Проведення зрізів стану } \\
\text { сформованості } \text { ІКК майбутніх } \\
\text { учителів початкової школи }\end{array}$ & $\begin{array}{c}\text { Анкетування, } \\
\text { тестування }\end{array}$ & $\begin{array}{l}\text { Ставлення, компетентність і рівні } \\
\text { сформованості ІКК майбутніх } \\
\text { учителів початкової школи }\end{array}$ & \multirow[t]{2}{*}{$\begin{array}{l}\text { Січень - } \\
\text { червень } \\
2018 \text { р. }\end{array}$} \\
\hline 4 & $\begin{array}{l}\text { Аналіз результатів оцінювання } \\
\text { ІКК }\end{array}$ & $\begin{array}{c}\text { Методи } \\
\text { математичної } \\
\text { статистики }\end{array}$ & $\begin{array}{l}\text { Рівні сформованості ІКК майбутніх } \\
\text { учителів початкової школи }\end{array}$ & \\
\hline 5 & $\begin{array}{l}\text { Виявлення та визначення } \\
\text { рівнів сформованості IКК } \\
\text { майбутніх учителів початкової } \\
\text { школи }\end{array}$ & $\begin{array}{c}\text { Система } \\
\text { оцінювання } \\
\text { рівнів IКК }\end{array}$ & $\begin{array}{l}\text { Рівні сформованості ІКК майбутніх } \\
\text { учителів початкової школи }\end{array}$ & \\
\hline \multicolumn{5}{|c|}{ III етап експерименту (2018-2020 н. р.) - поглиблювально-формувальний } \\
\hline 1 & $\begin{array}{lr}\text { Апробація, } & \text { впровадження } \\
\text { розробленої } & \text { системи } \\
\text { формування } & \text { IКК майбутніх } \\
\text { учителів початкової школи в } \\
\text { процес професійної підготовки }\end{array}$ & $\begin{array}{c}\text { Проведення } \\
\text { аудиторних } \\
\text { занять, поза- } \\
\text { аудиторних } \\
\text { заходів, } \\
\text { керівництво } \\
\text { педагогічною } \\
\text { практикою, } \\
\text { науковою } \\
\text { роботою }\end{array}$ & $\begin{array}{lrr}\text { Результати } & \text { дослідного } & \text { навчання } \\
\text { щодо впровадження } & \text { створеної } \\
\text { системи } & \text { формування } & \text { IКК } \\
\text { майбутніх } & \text { учителів } & \text { початкової } \\
\text { школи } & & \end{array}$ & \multirow{3}{*}{$\begin{array}{l}\text { Січень - } \\
\text { грудень } \\
2019 \text { р. }\end{array}$} \\
\hline 2 & 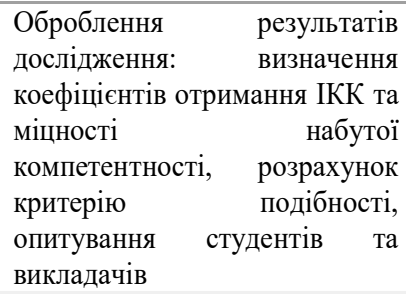 & $\begin{array}{l}\text { Коефіцієнти } \\
\text { отримання ІКК та } \\
\text { міцності набутої } \\
\text { компетентності } \\
\text { t-критерій, } \\
\text { анкетування }\end{array}$ & $\begin{array}{l}\text { Коефіцієнти отримання ІКК та } \\
\text { міцності набутої компетентності; } \\
\text { ступінь подібності чи різниці } \\
\text { контрольної та експериментальної } \\
\text { груп; } \\
\text { ставлення студентів та викладачів } \\
\text { до оцінювання ІКК }\end{array}$ & \\
\hline 3 & $\begin{array}{l}\text { Коригування розробленої } \\
\text { системи оцінювання ІКУ } \\
\text { майбутніх учителів початкової } \\
\text { школи }\end{array}$ & Логічні операції & $\begin{array}{l}\text { Внесення змін до розробленої } \\
\text { системи оцінювання ІКК майбутніх } \\
\text { учителів початкової школи }\end{array}$ & \\
\hline \multicolumn{5}{|c|}{ IV етап експерименту (2019-2020 н. р.) - аналітико-узагальнювальний } \\
\hline 1 & $\begin{array}{lr}\text { Формування } & \text { висновків щодо } \\
\text { результатів } & \text { дослідного } \\
\text { навчання } & \end{array}$ & Логічні операції & $\begin{array}{l}\text { Літературне оформлення } \\
\text { результатів експерименту }\end{array}$ & $\begin{array}{l}\text { Січень - } \\
\text { березень } \\
2020 \text { р. }\end{array}$ \\
\hline 2 & $\begin{array}{lr}\text { Розроблення } \\
\text { напрямів } \\
\text { створеної системи формусичнин } \\
\text { IКК }\end{array}$ & Логічні операції & $\begin{array}{l}\text { Остаточне } \\
\text { дисертаційного дослідження }\end{array}$ & $\begin{array}{c}\text { Квітень - } \\
\text { червень } \\
2020 \text { p. }\end{array}$ \\
\hline
\end{tabular}

враховувалися складність, багатогранність і багатокомпонентність процесу формування іншомовної комунікативної компетентності майбутніх учителів початкової школи. Враховуючи логіку педагогічного пошуку, було розроблено схему проведення педагогічного експерименту.

На першому етапі експерименту було сформульовано гіпотезу, визначено мету, завдання, структуру, виділено об'єкт контролю, критерії оцінювання ІКК студентів, які перевірялися наприкінці кожного семестру експериментального навчання за авторською методикою у студентів спеціальності 013 Початкова освіта.

Гіпотеза експериментального дослідження полягала у тому, що сформованості ІКК у здобувачів освіти факультетів початкової освіти можливо досягти шляхом цілеспрямованої інтеграції змісту іншомовної професійної підготовки майбутніх учителів початкової школи та впровадження авторської методики 
ОРГАНІЗАЦІЯ ПЕДАГОГІЧНОГО ЕКСПЕРИМЕНТУ 3 ФОРМУВАННЯ ІНШОМОВНОӤ КОМУНІКАТИВНОЇ КОМПЕТЕНТНОСТІ МАЙБУТНІХУЧИТЕЛІВ ПОЧАТКОВОӤ ШКОЛИ

\section{Вибір проблеми наукового дослідження}

Аналіз філософської, психолого-педагогічної, спеціальної літератури та практики сучасного стану розробленості проблеми формування IКК майбутніх учителів початкової школи з наступним синтезом його результатів у цілісну систему поглядів із метою визначення теоретико-методологічних засад дослідження
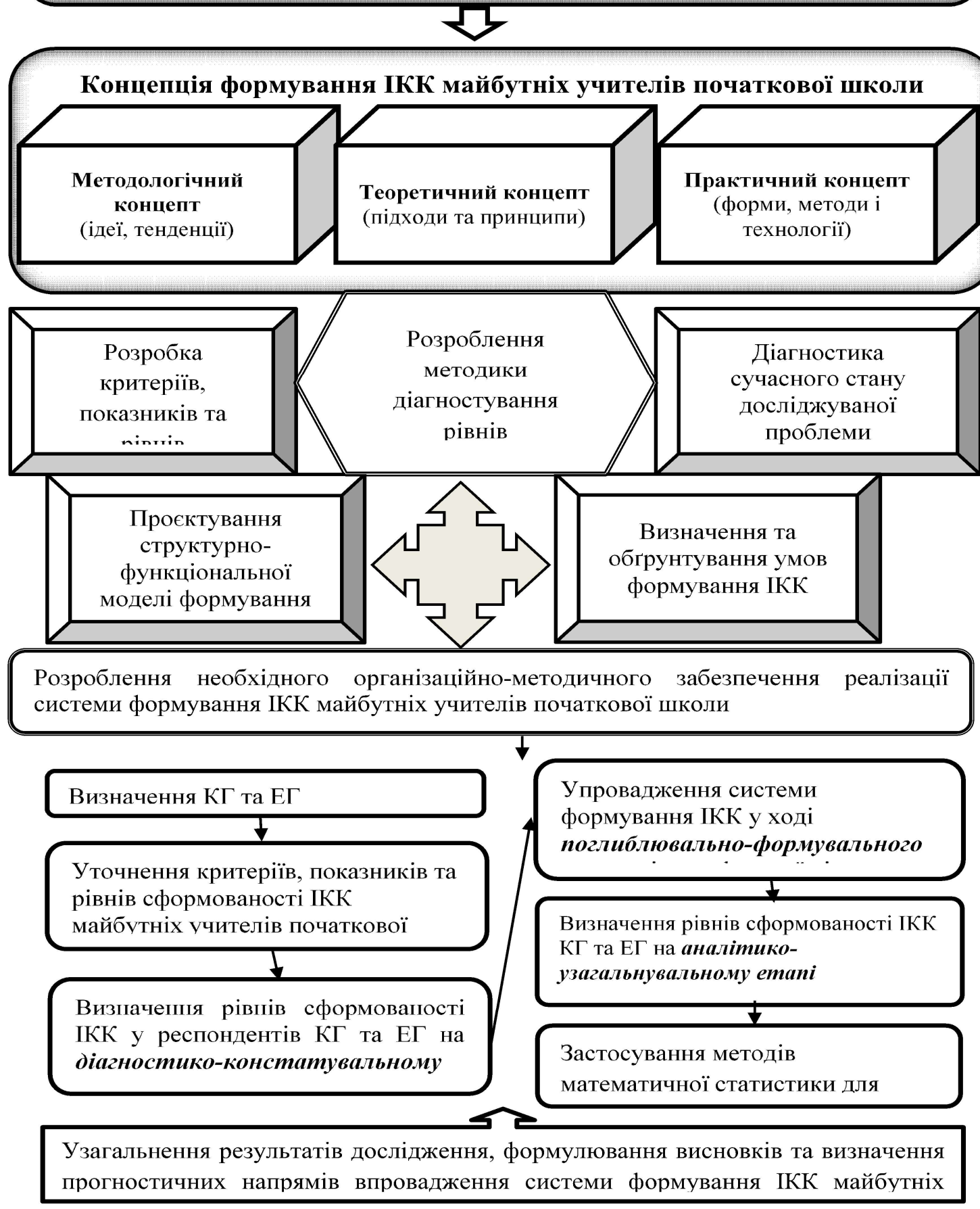

Рис. 2. Схема педагогічного експерименту з формування ІКК 
ОРГАНІЗАЦІЯ ПЕДАГОГІЧНОГО ЕКСПЕРИМЕНТУ З ФОРМУВАННЯ ІНШОМОВНОӤ КОМУНІКАТИВНОӤ КОМПЕТЕНТНОСТІМАЙБУТНІХУЧИТЕЛІВ ПОЧАТКОВОӤ ШКОЛИ

Таблиця 2.

Результати аналітико-узагальнювального етапу експерименту з формування іншомовної комунікативної компетентності

\begin{tabular}{|l|c|c|}
\hline \multicolumn{1}{|c|}{ Рівні } & KГ & EГ \\
\hline Інтуїтивний & $26,7 \%$ & $6,6 \%$ \\
\hline Репродуктивний & $53,3 \%$ & $60 \%$ \\
\hline Реконструктивний & $20 \%$ & $26,7 \%$ \\
\hline Еталонний & - & $6,7 \%$ \\
\hline
\end{tabular}

формування ІКК. Висунута нами гіпотеза передбачала такий наслідок: створена методика формування ІКК майбутніх учителів початкової школи, що базується на спеціально дібраному професійно-орієнтованому автентичному матеріалі й відеосюжетах дидактичної спрямованості, та структурно-функціональну модель системи формування ІКК, що має забезпечити ефективність формування ІКК. Відповідно до визначеної гіпотези, мета експериментального дослідження полягала в підтвердженні ефективності розробленої методики та визначенні адекватності й доцільності їі застосування в освітньому процесі.

Результати даних аналітико-узагальнювального етапу експерименту дають змогу стверджувати, що за допомогою методів математичної статистики було доведено: контрольна й експериментальна групи після впровадження розробленої системи формування ІКК різняться за рівнями володіння іншомовною комунікативною компетентністю. На відміну від контрольної групи, деяка частина студентів (6,7 \%) експериментальної групи вийшли на еталонний рівень володіння іншомовною комунікативною компетентністю, проте значно знизився відсоток респондентів, що володіють зазначеною якістю інтуїтивно (на найнижчому рівні) - 6,6 \%, хоча в контрольній групі цей відсоток залишився досить високим - 26,7\%. Найбільша кількість студентів експериментальної групи (60 \%), так як і контрольної (53,3%), перебувають на репродуктивному рівні. Відповідні дані зображено в таблиці 3.

Висновки та перспективи подальших досліджень. Таким чином, виявлена різниця між показниками рівнів сформованості досліджуваної якості у двох досліджуваних групах після реалізації системи формування іншомовної комунікативної компетентності майбутніх учителів початкової школи є статистично значимою, що свідчить про достатню результативність створеної системи формування іншомовної комунікативної компетентності майбутніх учителів початкової школи.

Перспективи подальших досліджень вбачаємо в обгрунтуванні прогностичних напрямів впровадження системи формування іншомовної комунікативної компетентності майбутніх учителів початкової школи.

\section{ЛІТЕРАТУРА}

1. Бегека Д. А. Підготовка майбутніх магістрів іноземної філології до формування фахової комунікативної компетентності студентів педагогічного університету: дис. ... канд. пед. наук. Національний педагогічний університет імені М. П. Драгоманова. 13.00.04 - теорія і методика професійної освіти. Київ. 2015. 246 с.

2. Бершадська Н. С. Методика формування англомовної усної дискурсивної компетенції у студентів мовних спеціальностей: дис. ... канд. пед. наук. 13.00.02 - теорія та методика навчання (германські мови). Державний заклад "Південноукраїнський національний педагогічний університет імені К. Д. Ушинського”. Одеса. 2011. $245 \mathrm{c}$.

3. Бурак М. І. Взаємопов'язане формування у майбутніх викладачів англійської мови професійно орієнтованої компетентності в говорінні та інформаційно-комунікаційної компетентності: дис. ... канд. пед. наук. 13.00.02. Тернопільський національний педагогічний університет імені Володимира Гнатюка. Тернопіль. 2019. 243 с.

4. Вяхк I. А. Педагогічні умови формування іншомовної комунікативної компетентності майбутніх учителів початкової школи: дис. ... канд. пед. наук. 13.00.04. Вінницький національний технічний університет. Вінниця. 2013. 227 с.

5. Дмитренко Г., Помиткін Е., Головач Н. Формування здатних до самореалізації здобувачів освіти в умовах глобалізованого світу. Молодь $i$ ринок. № 1 (180). 2020. С. $12-18$.

6. Загвязинский В. И., Поташник М. М. Как учителю подготовить и провести эксперимент. Москва, 2004. 144 с.

7. Карелин А. Большая энциклопедия психологических тестов. Москва, 2007. 416 с.

8. Краткая философская энциклопедия. Москва, 1994. 576 с.

9. Ляховицкий М. В. Общая методика 
обучения иностранным языкам: учеб. пособие для филол. фак. Вузов. Москва,1991. 306 с.

10. Общая психология: учебник для студентов пед. институтов. Под ред. А. В. Петровского. Москва, 1976. 479 с.

11. Пассов Е. И. Коммуникативный метод обучения иноязычному говорению. 2-е изд. Москва, 1991. 223 с.

12. Шиянюк Л. В. Текстоцентричний підхід до формування україномовної комунікативної компетентності студентів вищих технічних навчальних закладів I - II рівнів акредитації: дис. ... канд. пед. наук. 13.00.02 Теорія та методика навчання (українська мова). Херсонський державний університет. Херсон, 2018. 203 с.

\section{REFERENCES}

1. Beheka, D. A. (2015). Pidhotovka maybutnikh mahistriv inozemnoyi filolohiyi do formuvannya fakhovoyi komunikatyvnoyi kompetentnosti studentiv pedahohichnoho universytetu [Training future masters of foreign philology for the forming professional communicative competence of pedagogical university students]. Candidate's thesis. Kyiv. 246 p. [in Ukrainian].

2. Bershadska, N. S. (2011). Metodyka formuvannya anhlomovnoyi usnoyi dyskursyvnoyi kompetentsiyi u studentiv movnykh spetsialnostey [Methodology of forming English oral discursive competence of language specialties students]. Candidate's thesis. Odessa, 245 p. [in Ukrainian].

3. Burak, M. I. (2019). Vzayemopovyazane formuvannya u maybutnikh vykladachiv anhliyskoyi movy profesiyno oriyentovanoyi kompetentnosti $\mathrm{v}$ hovorinni ta informatsiyno-komunikatsiynoyi kompetentnosti [Interrelated forming future English teachers' professionally oriented competence in speaking, information and communication competence]. Candidate's thesis. Ternopil, 243 p. [in Ukrainian].

4. Vyakhk, I. A. (2013). Pedahohichni umovy formuvannya inshomovnoyi komunikatyvnoyi kompetentnosti maybutnikh uchyteliv pochatkovoyi shkoly [Pedagogical conditions of formation of foreign communicative competence of future primary school teachers]. Candidate's thesis. Vinnytsia National Technical University. Vinnytsia, 227 p. [in Ukrainian].

5. Dmytrenko, H., Pomytkin, E., \& Holovach, N. (2020). Formuvannya zdatnykh do samorealizatsiyi zdobuvachiv osvity v umovakh hlobalizovanoho svitu [Formation of students' self-fulfilling in a globalized world]. Youth and the market. Vol. 1 (180). pp. 12 - 18. [in Ukrainian].

6. Zagvyazinskiy, V. I., \& Potashnik, M. M. (2004). Kak uchiteliu podgotovit $i$ provest $i$ éksperiment [How can a teacher prepare and conduct an experiment]. Moscov, 144 p. [in Russian].

7. Karelin, A. (2007). Bolshaya éntsyklopediya psikhologicheskikh testov [Large encyclopedia of psychological tests]. Moscow, 416 p. [in Russian].

8. Kratkaya filosofskaya éntsyklopediya. (1994). [A brief philosophical encyclopedia]. Moscov, 576 p. [in Russian].

9. Liakhovitskiy, M. V. (1991). Obshchaya metodika obucheniya inostrannym yazykam [General methods of teaching foreign languages]: textbook. manual for philol. fac. university. Moscov, 306 p. [in Russian].

10. Obshchaya psikhologiya (1976). [General psychology]: a textbook for students of ped. institutions. (Ed.). A. V. Petrovsky. Moscov, 479 p. [in Russian].

11. Passov, Ye. I. (1991). Kommunikativnyy metod obucheniya inoyazychnomu govoreniyu [Communicative method of teaching foreign language speaking]. 2nd ed. Moscov, 223 p. [in Russian].

12. Shyianiuk, L. V. (2018). Tekstotsentrychny pidkhid do formuvannya ukrayinomovnoyi komunikatyvnoyi kompetentnosti studentiv vyshchykh tekhnichnykh navchalnykh zakladiv I - II rivniv akredytatsiyi [Text-centric approach to the forming Ukrainian-language communicative competence of the students of higher technical educational institutions of I - II levels of accreditation]. Candidate's thesis. Kherson State University. Kherson, 203 p. [in Ukrainian].

Стаття надійшла до редакції 25.05.2020

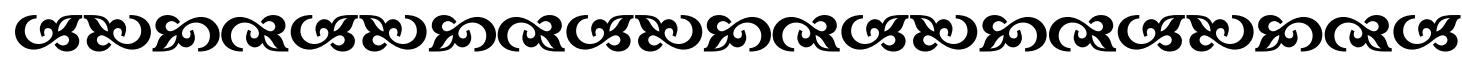

"Хто хоче зрушити світ, нехай зрушить себе!"

Cospam

давньогреиький білособ

“Фля того, щоб прийти до справжнъого знання, треба спочатку відчути сумніви”.

\section{G58080}

